\title{
Effectiveness of Lichtenstein repairs in planned treatment of giant inguinal hernia - own experience
}

\author{
Jacek Bierca, Anna Kosim, Małgorzata Kołodziejczak, Jan Zmora, Ewa Kultys \\ Department of Surgery with Subdepartment of Proctology, Hospital at Solec, Warsaw, Poland
}

Videosurgery Miniinv 2013; 8 (1): 36-42 DOI: $10.5114 /$ wiitm.2011.30971

\begin{abstract}
Introduction: Occurrence of giant inguinal hernias is not frequent because of growing medical awareness in the community as well as progress in surgical treatment in this field.

Aim: To evaluate the effectiveness of repairs using the Lichtenstein technique in scheduled treatment of giant inguinal hernias

Material and methods: Between 2006 and 2010 in the Department of Surgery with the Subdepartment of Proctology, Hospital at Solec in Warsaw, 909 repairs of inguinal hernia were performed, including 15 patients (1.65\%) with the diagnosis of giant hernia. In 3 cases it was direct inguinal hernia and in 12 cases indirect inguinal hernia. All giant hernias occurred in male patients between 33 and 87 years of age (mean age 65 years old) and developed for many years, median of 14.2 years. All patients underwent scheduled repairs using the tension-free Lichtenstein technique. A non-absorbable polypropylene mesh was used for hernioplasty. Exact Fisher's test $(p<0.01)$ was used for statistical analysis.

Results: In all cases contents of the hernial sac consisted of loops of small intestine, colon and omentum. Early complications occurred in 11 patients (73\%) in the group of patients with giant hernias, whereas in the remaining group of patients early complications occurred in 53 patients (5.9\%). The difference was statistically significant. In the group of patients with giant hernias no recurrence was observed over the observation period ranging from 6 months to 4.5 years. In the remaining group of patients recurrences occurred in 23 patients (2.6\%).

Conclusions: The Lichtenstein technique of repair is effective in management of giant inguinal hernias. A statistically significantly higher percentage of complications was observed in the group of patients with giant hernias as compared to the remaining group of patients with inguinal hernias. Patients with giant hernias require proper preparation for surgery, especially in relation to their respiratory efficiency.
\end{abstract}

Key words: giant hernia, inguinal hernia, Lichtenstein technique.

\section{Introduction}

Inguinal hernia repairs are the most frequently performed surgical procedures. The number of annual procedures is estimated at 800000 in the USA and 100000 in Poland. The assessment suggests that the hernia occurrence rate is $27 \%$ in men and $3 \%$ in women within the lifetime [1-3]. This report deals with giant hernia, a particular kind of hernia in which the hernia sac is below the point located on the inner area of the thigh, in the middle of its length when a patient is in a standing position [4]. Nowadays, the occurrence of giant hernias is not frequent. It is influenced by both the increased medical awareness of society and the advancement of surgical treatment. Multi-annual disease status, obesity and delayed surgical management all favor the development of giant 
hernias. Publications concerning giant hernias are based on small series of patients and often on single cases [5-9]. Tension-free repair of inguinal hernias was described by Lichtenstein in 1987 and is considered by many a "gold standard" in surgical inguinal hernia management $[10,11]$. Tension-free methods of hernia repair are divided into anterior and posterior, depending on mesh placement in relation to the transverse fascia. The Lichtenstein technique is placed in the category of anterior hernioplasties [12]. The original Lichtenstein technique consisted in reinforcement of the posterior wall of the inguinal canal with a polypropylene patch. The lateral edge of the mesh was fixed with a 2.0 non-absorbable, monofilament suture to the inguinal ligament. The peripheral part was sewn over to the aponeurosis covering the pubic bone with the margin of $1.5-2 \mathrm{~cm}$. The medial edge of the mesh was fixed to the aponeurosis of the transverse and internal oblique muscle [10]. Although the method has undergone various modifications, the general rule remains the same: it consists in mesh placement on the fascia and decrease in tissue tension $[11,13]$. The material that meshes are made of should fulfill the following conditions: be easy to shape and cut, resistant to infection and also easy for the tissues to grow in. In the presented series, heavy, completely non-absorbable, polypropylene meshes were used.

\section{Aim}

The aim of the study was to assess the effectiveness of surgery using the Lichtenstein technique in elective giant inguinal hernia management.

\section{Material and methods}

From 2006 to 2010 in the Department of Surgery with the Subdepartment of Proctology, Hospital at Solec in Warsaw, 909 inguinal hernia repairs were performed. Giant hernias were diagnosed in 15 cases (1.65\%) (Photo 1). All of them occurred in males aged from 33 to 87 years old (median age 65 years old) and had developed over many years - from 7 to 23 years (14.2 years on average). Body mass index (BMI) was calculated in all patients with giant hernias. The group is characterized in Table I. There were no patients with clinical symptoms of mechanically obstructed intestines observed. 894 with "standard" inguinal hernia constituted the control group. Men predominated; there were 784 of them and the series included 142 female patients. "Standard" hernias occurred in patients aged from 18 to 91 years old (median age: 68 years old). Often the patients operated on had a positive history of concurrent diseases, mainly circulatory system disorders $(521=58 \%)$ and diabetes $(213=24 \%)$.

All the patients with giant inguinal hernia were operated on electively, under general anesthesia, using the tension-free Lichtenstein technique. In 9 cases (60\%) additional surgical procedures were performed such as omentectomy, appendectomy and orchiectomy.

\section{Description of the surgical method}

Cutaneous incision $2-3 \mathrm{~cm}$ above the inguinal ligament. Incision through subcutaneous tissue as far as the aponeurosis of the abdominal external oblique muscle. Opening the inguinal canal, hernial sac dissection. Sac opening, its contents invaginated into the peritoneal cavity, frequently after freeing numerous interloop adhesions. Dissection of spermatic cord elements (Photo 2). Cutting the hernia sac in the middle of inguinal canal, preparation, underpinning and ligation of the proximal portion of the sac, excess hernia sac excised. The proximal part of the sac thus prepared was pushed back into the peritoneal cavity. The distal part was left wide open without preparation (Photo 3). In convenient technical conditions the edges of transverse fascia were closed with a continuous, absorbable 3.0 suture. The polypropylene mesh sized $6-8 \mathrm{~cm} \times 10-12 \mathrm{~cm}$ was placed at the floor of the inguinal canal, its lower edge being fixed to the inguinal ligament up to the

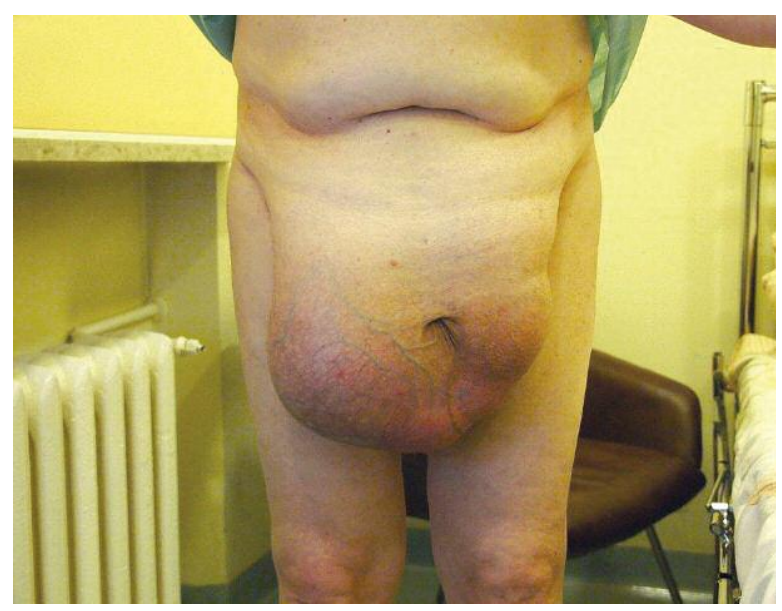

Photo 1. Giant inguinal hernia 
Table I. Characteristics of study group

\begin{tabular}{|c|c|c|c|c|c|c|}
\hline No. & Sex & $\begin{array}{c}\text { Age } \\
\text { [years] }\end{array}$ & $\begin{array}{c}\text { Body mass } \\
\text { index }(\mathrm{BMI}) \\
{\left[\mathrm{kg} / \mathrm{m}^{2}\right]}\end{array}$ & $\begin{array}{c}\text { Concurrent diseases } \\
\text { duration }\end{array}$ & $\begin{array}{l}\text { Disease } \\
\text { of hernia }\end{array}$ & Type \\
\hline 1 & M & 78 & 32 & Coronary artery disease, diabetes & 23 & Oblique inguinal hernia \\
\hline 2 & $M$ & 67 & 28 & Arterial hypertension & 11 & Direct inguinal hernia \\
\hline 3 & $M$ & 66 & 33 & Arterial hypertension, diabetes & 16 & Direct inguinal hernia \\
\hline 4 & M & 79 & 34 & Coronary artery disease & 8 & Oblique inguinal hernia \\
\hline 5 & M & 65 & 23 & Asthma & 10 & Oblique inguinal hernia \\
\hline 6 & M & 64 & 36 & Arterial hypertension & 21 & $\begin{array}{l}\text { Oblique inguinal hernia, } \\
\text { sliding }\end{array}$ \\
\hline 7 & M & 64 & 35 & Diabetes, arterial hypertension & 15 & Oblique inguinal hernia \\
\hline 8 & M & 33 & 40 & Diabetes & 8 & Oblique inguinal hernia \\
\hline 9 & M & 76 & 28 & & 16 & $\begin{array}{l}\text { Oblique inguinal hernia, } \\
\text { sliding }\end{array}$ \\
\hline 10 & M & 47 & 28 & & 7 & Direct inguinal hernia \\
\hline 11 & M & 55 & 20 & Chronic obstructive lung disease & 18 & Oblique inguinal hernia \\
\hline 12 & M & 51 & 42 & Arterial hypertension & 16 & Oblique inguinal hernia \\
\hline 13 & M & 51 & 34 & Arterial hypertension & 11 & Oblique inguinal hernia \\
\hline 14 & M & 87 & 24 & Coronary artery disease & 21 & $\begin{array}{l}\text { Oblique inguinal hernia, } \\
\text { sliding }\end{array}$ \\
\hline 15 & $M$ & 87 & 33 & Arterial hypertension, renal failure & 12 & Oblique inguinal hernia \\
\hline
\end{tabular}

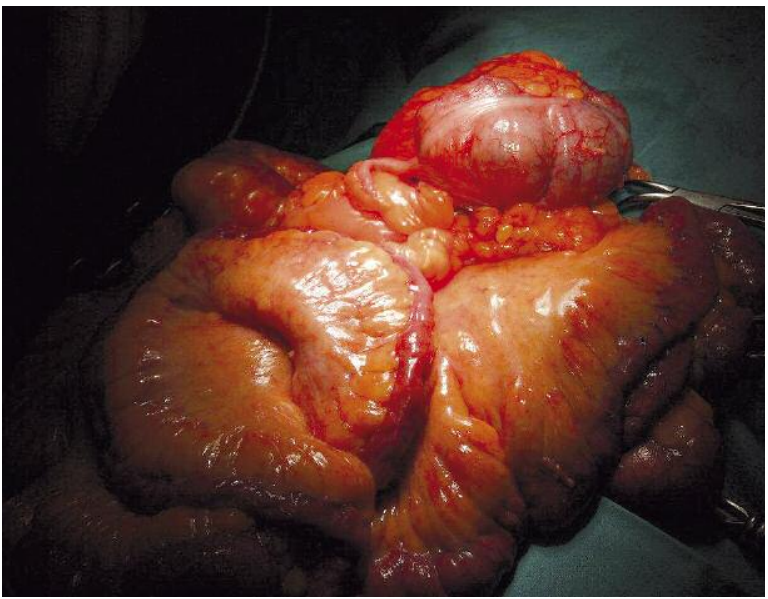

Photo 2. The contents of the hernia sac

level of the inguinal ring with a continuous, nonabsorbable 3.0 Prolene suture. The mesh was cut from above towards the inguinal ring in such a man-

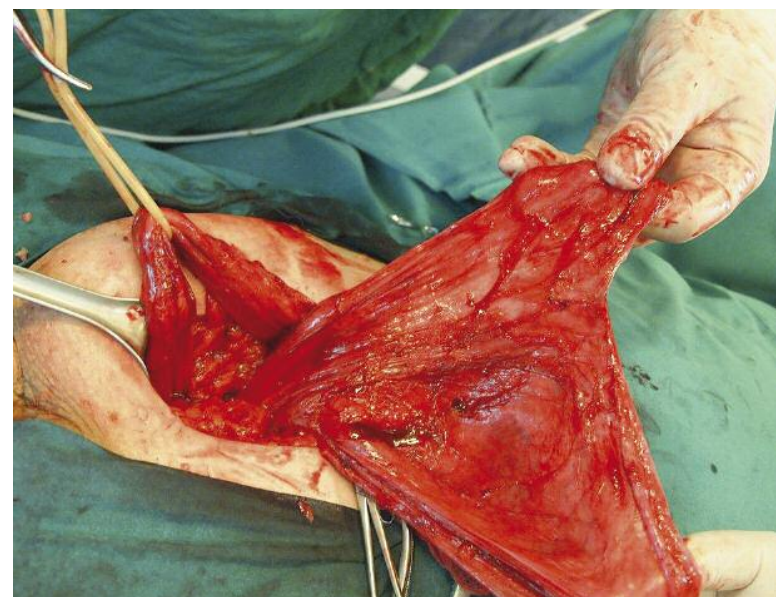

Photo 3. Dissected spermatic cord and hernia $\mathrm{sac}$

ner that its lower part constitutes $1 / 3$ and the upper part $2 / 3$. The cut edges of the mesh were closed with a single suture in order to fit them well around the 
spermatic cord so that a deep inguinal ring was created. The upper edge of the mesh was fixed with single, loose, non-absorbable suture under the aponeurosis of the abdominal internal oblique muscle (Photo 4). The aponeurosis of the abdominal external oblique muscle was ligatured with a continuous, nonabsorbable 3.0 Prolene suture. In all the cases the postoperative wound was typically closed with a Redon drain left on the mesh inserted through a separate incision. The drain was removed on the $2^{\text {nd }} 4^{\text {th }}$ postoperative day. In 9 patients additional procedures were performed. In 7 of them omentectomy was performed, in 2 appendectomy and in 1 a testicle was removed with the spermatic cord. No intestinal resection was performed. Antibiotic prophylaxis which consisted of 1 dose of cyclosporine administered 30 min before the procedure was used in all the patients. It was continued in 6 cases due to additional procedures or prolonged time of the hernioplasty itself. In all the patients anticoagulant prophylaxis was employed. In the postoperative period patients were activated early and underwent respiratory rehabilitation. The length of hospital stay varied from 3 to 10 days ( 6.3 days on average). All the patients attended follow-up appointments on the $7^{\text {th }}$, $30^{\text {th }}, 180^{\text {th }}$ day and 2 and 4 years after the procedure. The method of statistical analysis: Fisher's test. The accepted level of significance: $p<0.01$.

\section{Results}

Recurrent hernia was not observed in any of the patients with giant hernias. The results of giant hernia management in the form of early complications and recurrence are presented in Table II. Early postoperative complications occurred in 11 patients (73\%) with giant hernia. Despite the routine drainage of the postoperative wound, wide, subcutaneous hematoma occurred in the area operated on and the scrotum. It took place in 5 cases and did not require surgical revision. In 3 cases, serotoma appeared involving several punctures and aspiration of serous contents in 2 patients. 20 to $160 \mathrm{ml}$ were withdrawn at one time. Local infection of the postoperative wound occurred in 2 patients; it was tackled by antibiotic therapy. Clinical symptoms of neuralgia of the genitofemoral nerve were observed in 1 patient. They remitted after the use of non-steroid anti-inflammatory drugs and analgesics. Over the observation period ranging from 6 months to 4.5 years no recurrence was observed in

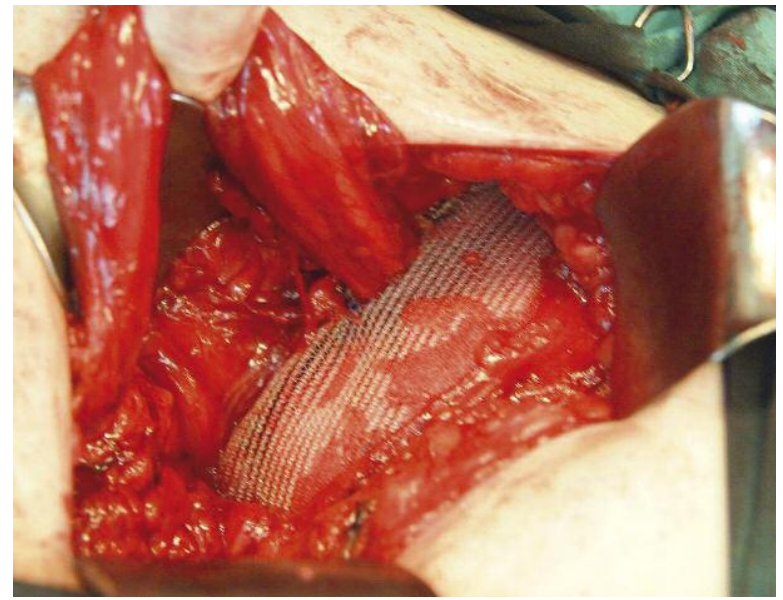

Photo 4. Final stage of the procedure

the series of patients with giant hernias. In the group of patients with inguinal hernia early complications occurred in 53 patients (5.9\%), and hernia recurrence took place in 23 cases (2.6\%). The results of hernia management in patients with "standard" hernia are presented in Table III. The difference turned out to be statistically significant (Table IV).

\section{Discussion}

All the procedures in the research group were performed under endotracheal anesthesia. The choice of anesthesia was dictated by the necessity to create optimal conditions (atonic abdominal wall) to remove the contents of the hernia sac into the peritoneal cavity and the predicted possibility of additional procedures, which took place in $60 \%$ of the patients operated on. Patient selection for the procedure should be especially careful as the sudden push back of the contents may lead to symptoms of abdominal compartment syndrome, which may result in respiratory failure. In the analyzed group, the patients were consulted by an anesthesiologist before hospital admission and their cardio-pulmonary competence was assessed.

The patients were monitored for respiratory and circulatory status so that possible symptoms of abdominal compartment syndrome could be discovered early. Early rehabilitation and activation of patients were important prophylactic factors. It is worth mentioning that in the series of patients with giant hernias no respiratory complications were observed. In 9 patients (60\%) with giant hernia addi- 
Table II. Results of surgical management of patients with giant hernias

\begin{tabular}{|c|c|c|c|c|}
\hline $\begin{array}{l}\text { Patient } \\
\text { number }\end{array}$ & $\begin{array}{c}\text { Hernial } \\
\text { sac contents }\end{array}$ & $\begin{array}{l}\text { Type and range } \\
\text { of procedure }\end{array}$ & $\begin{array}{c}\text { Early } \\
\text { complications }\end{array}$ & $\begin{array}{l}\text { Hernia } \\
\text { recurrence }\end{array}$ \\
\hline 1 & $\begin{array}{l}\text { Loops of small intestine, } \\
\text { omentum }\end{array}$ & $\begin{array}{l}\text { Partial omental resection, } \\
\text { Lichtenstein procedure }\end{array}$ & Superficial wound infection & $\begin{array}{l}\text { No recurrence }-4.5 \text { year } \\
\text { observation period }\end{array}$ \\
\hline 2 & Greater omentum & $\begin{array}{l}\text { Partial omental resection, } \\
\text { Lichtenstein procedure }\end{array}$ & $\begin{array}{l}\text { Hematoma in the area of the } \\
\text { postoperative wound and } \\
\text { scrotum }\end{array}$ & $\begin{array}{l}\text { No recurrence }-4 \text { year } \\
\text { observation period }\end{array}$ \\
\hline 3 & Loops of small intestine & Lichtenstein procedure & Hematoma in the scrotum area & $\begin{array}{l}\text { No recurrence }-4 \text { year } \\
\text { observation period }\end{array}$ \\
\hline 4 & $\begin{array}{l}\text { Loops of small intestine, } \\
\text { omentum }\end{array}$ & Lichtenstein procedure & None & $\begin{array}{l}\text { No recurrence }-3.5 \text { year } \\
\text { observation period }\end{array}$ \\
\hline 5 & Greater omentum & $\begin{array}{l}\text { Partial omental resection, } \\
\text { Lichtenstein procedure }\end{array}$ & None & $\begin{array}{c}\text { No recurrence }-3.5 \text { year } \\
\text { observation period }\end{array}$ \\
\hline 6 & $\begin{array}{l}\text { Loops of colon, and } \\
\text { sigmoid colon was a part } \\
\text { of the hernial sac }\end{array}$ & Lichtenstein procedure & None & $\begin{array}{l}\text { No recurrence }-3 \text { year } \\
\text { observation period }\end{array}$ \\
\hline 7 & $\begin{array}{l}\text { Cecum with vermiform } \\
\text { appendix }\end{array}$ & $\begin{array}{l}\text { Appendectomy, Lichtenstein } \\
\text { procedure }\end{array}$ & Superficial wound infection & $\begin{array}{l}\text { No recurrence }-3 \text { year } \\
\text { observation period }\end{array}$ \\
\hline 8 & Greater omentum & $\begin{array}{l}\text { Partial omental resection, } \\
\text { Lichtenstein procedure }\end{array}$ & $\begin{array}{l}\text { Hematoma reaching the } \\
\text { scrotum area }\end{array}$ & $\begin{array}{l}\text { No recurrence }-3 \text { year } \\
\text { observation period }\end{array}$ \\
\hline 9 & $\begin{array}{l}\text { Transverse colon witch } \\
\text { omentum loops of small } \\
\text { intestine and cecum, } \\
\text { which was the wall } \\
\text { of the hernia sac }\end{array}$ & $\begin{array}{l}\text { Omental resection, testicle } \\
\text { and spermatic cord removal. } \\
\text { Inguinal canal plasty with } \\
\text { a polypropylene mesh }\end{array}$ & Scrotal hematoma & $\begin{array}{l}\text { No recurrence }-3 \text { year } \\
\text { observation period }\end{array}$ \\
\hline 10 & Greater omentum & $\begin{array}{l}\text { Partial omental resection, } \\
\text { Lichtenstein procedure }\end{array}$ & None & $\begin{array}{l}\text { No recurrence }-2.5 \text { year } \\
\text { observation period }\end{array}$ \\
\hline 11 & Loops of small intestine & Lichtenstein procedure & Scrotal serotoma & $\begin{array}{l}\text { No recurrence }-2 \text { year } \\
\text { observation period }\end{array}$ \\
\hline 12 & $\begin{array}{l}\text { Loops of colon, greater } \\
\text { omentum }\end{array}$ & Lichtenstein procedure & Scrotal serotoma & $\begin{array}{l}\text { No recurrence }-2 \text { year } \\
\text { observation period }\end{array}$ \\
\hline 13 & Loops of small intestine & Lichtenstein procedure & $\begin{array}{l}\text { Neuralgia of the } \\
\text { genitofemoral nerve }\end{array}$ & $\begin{array}{l}\text { No recurrence }-10 \text { month } \\
\text { observation period }\end{array}$ \\
\hline 14 & $\begin{array}{l}\text { Loops of small intestine, } \\
\text { cecum, which was the } \\
\text { wall of the hernia sac }\end{array}$ & $\begin{array}{l}\text { Appendectomy, Lichtenstein } \\
\text { procedure }\end{array}$ & Scrotal hematoma & $\begin{array}{l}\text { No recurrence }-6 \text { month } \\
\text { observation period }\end{array}$ \\
\hline 15 & $\begin{array}{l}\text { Loop of sigmoid colon, } \\
\text { greater omentum }\end{array}$ & $\begin{array}{l}\text { Partial omental resection, } \\
\text { Lichtenstein procedure }\end{array}$ & $\begin{array}{c}\text { Serotoma of the spermatic } \\
\text { cord sheaths }\end{array}$ & $\begin{array}{l}\text { No recurrence }-6 \text { month } \\
\text { observation period }\end{array}$ \\
\hline
\end{tabular}

tional procedures were performed. Omental resection was performed most frequently; it decreased the contents of the hernial sac successfully and facilitated invagination to the peritoneal cavity. No widening of the hernia ring was required in any of the patients in order to push back the contents of the hernia sac. In the analyzed series of patients with giant hernia tension-free Lichtenstein repair turned out to be effective in all the cases. Other authors report good results with the use of the above men- 
Table III. Results of surgical treatment of 894 patients with 'standard' inguinal hernias

\begin{tabular}{|ccc|}
\hline Complications & Number of patients & Percentage \\
\hline Early: & 53 & 5.9 \\
\hline • Postoperative wound infection & 31 & 3.5 \\
\hline • Hematoma in the postoperative area & 12 & 1.3 \\
\hline - Serotoma & 6 & 0.7 \\
\hline • Neuralgia & 4 & 0.4 \\
\hline Hernia recurrence & 23 & 2.6 \\
\hline
\end{tabular}

Table IV. Comparison of treatment of patients with standard and giant hernias

\begin{tabular}{|cccccc|}
\hline Inguinal hernia & Number of patients & Early complications & Percentage & Recurrence & Percentage \\
\hline Giant & 15 & 11 & 73 & 0 & 0 \\
\hline "Standard" & 894 & 53 & 5.9 & 23 & 2.6 \\
\hline
\end{tabular}

tioned method in giant hernia management [5]. In the presented group, all the patients with giant hernias received a prophylactic dose of antibiotics. Antibiotic therapy was continued in $40 \%$ of the people operated on. The role of antibiotic therapy in hernia repair using the Lichtenstein technique is arguable and questioned by some authors [14, 15]. Although the number of randomized studies considering this matter is small [16], in the case of giant hernias most authors agree that administration of antibiotics is necessary [17]. Also in the case of standard, uncomplicated hernioplasties the majority of Polish authors are in favor of antibiotic prophylaxis. However, there are contrary opinions of some authors who do not support routine administration of antibiotics [11]. During giant hernia repair some technical aspects have to be taken into account: existing adhesions among intestinal loops which comprise the contents of the hernial sac have to be freed especially neatly and carefully; its contents may be potentially difficult to reduce; additional procedures may have to be performed; drainage of the operative wound needs to be employed; and the size of the implanted mesh must be properly chosen. Animal testing shows that meshes can reduce their size by as much as $50 \%$, which is why a well-fitting appliance is so important [18-20]. It is especially important in giant hernia repair where the mesh implanted is required to have an adequately large margin [13].
In the analyzed series of patients with giant hernias a higher rate of early complications (hematoma, serotoma) was observed in comparison to the rest of patients with standard inguinal hernias (Table IV). The difference turned out to be statistically significant. Also other authors emphasize the higher possibility of early complications in this group of patients [5]. Careful hemostasis is significant in prevention of infective complications. Complications of hematoma may lead to wound infection which in the case of the Lichtenstein technique may result in massive infection and separation of the layers of a surgical wound. That is why checking Redon's drain for patency is so crucial on the $1^{\text {st }}$ postoperative day. Giant hernia repair in men often has to be combined with orchiectomy. Some reports show removal of testicles in all patients with giant hernias operated on [5]. In the case of a larger scrotal hernia, the sac may be firmly attached to the structures of the spermatic cord, which may be constricted and ischemic due to inflamed surrounding tissues. The need for orchiectomy is supported by frequent atrophy of a testicle in those cases and by the fact that inguinal canal plasty is easier to perform after removal of the testicle [5]. In our material the removal of a testicle took place in 1 case only (6.6\%). Patients with giant hernias are often seriously obese. In the presented material the average BMI was $31.2 \mathrm{~kg} / \mathrm{m}^{2}$. That is why early rehabilitation is an important factor decreasing 
the risk of early postoperative complications. This aspect of giant hernia management is emphasized by other authors too $[6,21]$. Good cooperation with the anesthesia team helps avoid cardiopulmonary complications. Early patient activation and low-molecular-weight heparin prophylaxis are recommended as they reduce the risk of thromboembolic complications.

\section{Conclusions}

Inguinal hernia repair using the Lichtenstein method is a successful method in giant hernia management. A statistically significantly higher percentage of complications was observed in the series of patients with giant hernias in comparison to the other patients with inguinal hernias. Patients with giant hernias require appropriate preparation and respiratory competence should be especially taken into account.

\section{References}

1. Kingsnorth A, LeBlanc K. Hernias: inguinal and incisional. Lancet 2003; 362: 1561-71.

2. Rutkow IM, Robbins AW. Demographic, classificatory and socioeconomic aspects of hernia repair in the United States. Surg Clin North Am 1993; 73: 413-26.

3. Pierściński J, Szopiński J, Szmytkowski S, Dąbrowicki. Attempted assessment of the incidence and cost of surgical hernies in Poland in the years 2001-2002. Przegl Epidemiol 2005; 59: 981-6.

4. Hodgkinson DJ, MC Ilrath DC. Scrotal reconstruction for giant hernias. Surg Clin North Am 1984; 64: 307-12.

5. Struniolo G, Tonante A, Gagliano E, et al. Surgical treatment of the giant inguinal hernia. Hernia 1999; 3: 27-30.

6. Tahir M, Ahmed FU, Seenu V. Giant inguinoscrotal hernia: case report and management principles. Int J Surg 2008; 6: 495-7.

7. Forrest J. Repair of massive inguinal hernia with pneumoperitoneum and without using prostetic mesh. Arch Surg 1979; 114: 1087-8.

8. Mehendale F, Taams K, Kingsnorth A. Repair of giant inguinoscrotal hernia. Br J Plastic Surg 2000; 53: 525-9.

9. Osemek P, Paśnik K, Trojanowski P. Case report. Huge, irreducible femoral interpreted as a preperitoneal lopoma in radiological findings. Videosurgery Miniinv 2010; 5: 35-7.

10. Lichtenstein IL, Shulman AG, Amid PK, Montlor MM. The tension-free hernioplasty. Am J Surg 1989; 157: 188-93.

11. Matyja A, Kilbil W, Pach R, et al. Assessment of inguinal hernia treatment results in patients operated on with mesh using. Videosurgery Miniinv 2010; 5: 27-34.

12. Pielaciński K, Wróblewski T, Wójtowicz J. Results of inguinal hernia repair by Lichtenstein method in material of Surgical Ward of the District Hospital in Żyrardow. Videosurgery Miniinv 2007; 2: 66-75.
13. Woods B, Neumayer L. Open repair of inguinal hernia: an evidence-based review. Surg Clin North Am 2008; 88: 139-55.

14. Kurzer M, Belsham PA, Kark AE. The Lichtenstein repair. Surg Clin North Am 1998; 78: 1025-46.

15. Aufenacker TJ, Van Geldere D, Van Mesdag T, et al. The role of antibiotic prophylaxis in prevention of wound infection after Lichtenstein open mesh repair of primary inguinal hernia: a multicenter double-blind randomized controlled trial. Ann Surg 2004; 240: 955-60.

16. Shankar VG, Srinivasan K, Sistla SC, Jagdish S. Prophylactic antibiotics in open mesh repair of inguinal hernia - a randomized controlled trial. Int J Surg 2010; 8: 444-7.

17. Terzi C. Antimicrobial prophylaxis in clean surgery with special focus on inguinal hernia repair with mesh. J Hosp Infect 2006; 62: 427-36.

18. Trivellini G, Bagni C, Sollini A, et al. Repair of giant hernias using more prosthesis. Hernia 2001; 5: 124-8.

19. Cobb WS, Burns JM, Peidl RC, at al. Textile analysis of heavy weight, mid-weight, and light weight polypropylene mesh in a porcine4 ventral hernia model. J Surg Res 2006; 136: 1-7.

20. Coda A, Bendavid R, Botto-Micca F, et al. Structural alterations of prosthetic mesh in humans. Hernia 2003; 7: 29-34.

21. El-Dessouki N. Prepeitoneal mesh hernioplasty in giant inguinoscrotal hernias: a new technique with dual benefit in repair and abdominal rooming. Hernia 2002; 5: 177-81.

Received: 3.06.2012, revised: 30.08.2012, accepted: 20.09.2012. 